\title{
The Review of Sponge City
}

\author{
Menglong Xing ${ }^{1, ~ a, ~ Y a m e i ~ H a n ~}{ }^{2, b}$, Minmin Jiang ${ }^{2, \mathrm{c}}$, Haixiang $\mathrm{Li}^{\star, \mathrm{d}}$ \\ ${ }^{12}$ College of Environmental Science and Engineering, GuiLin University of Technology, Guilin \\ 541006, China \\ *Guangxi Key Laboratory of Environmental Pollution Control Theory and Technology, Guilin \\ University of Technology, Guilin 541004, China

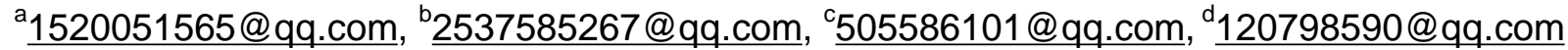

Keywords: Sponge city; Historical development; The status quo; Advice

Abstract. This paper summarizes the historical development of sponge cities at home and abroad and the status quo, and put forward some feasible suggestions to promote the sponge construction of city in our country.

\section{Introduction}

Lack of water resources, per capita is less than a quarter of the world's average for China. With the accelerating of urbanization process, many problems also arise. The various reasons of urban waterlogging: the city makes the heat cannot be evacuated, then local air currents could rise the probability of occurring of flow rainfall; The hard surfacing penetration ability in urban is bad, surface runoff will increase, and the non-point source pollution of the rainfall runoff is second only to the agricultural; the air in the city has condensation nuclei that prompt rainfall, and so on. Sponges city through the construction of the "green" measures on the rain water absorption, water storage, water seepage and water purification, when people need the accumulation of water. This way, urban waterlogging problems will gradually ease disappear under the construction of sponge city. [1-2].

\section{The development of the sponge city}

The development of the sponge city abroad. In the 1970s, America's "best management practices (Best Management Practices-- referred BMPs)" can be used to manage non-point source pollution, rainfall runoff and water quality. By the late 1990s, or the United States proposed a "low-impact development (Low Impact Development-- referred LID)" concept, in order to achieve the intended storm runoff and pollution control, and the use of small-scale design makes the diverging source close to nature management area water cycle. LID is an eco-system technology, you can easily achieve the city's rainwater harvesting, it lies in situ collection, natural purification, or take advantage of nearby groundwater recharge. The construction includes ecological ditch grass, sunken green space, rain gardens, green roofs, permeable pavement, and seep underground storage facilities. In August 1999, the United States proposed a "green infrastructure" concept. Green infrastructure is a national system of protected natural life, its constituent elements of water, flora and fauna, habitats, nature reserves and wilderness and the like. They maintain ecological processes, clean air and water, will help improve the health status and quality of life.

The development of the sponge city in China. The concept of the "SpongeBob city" was first proposed in the "2012 Low Carbon Urban and Regional Development of Science and Technology Forum" in Shenzhen that was held in the Peking University, China in April 2012. But the concept is not very original, and its content has rain floods appeared adjusted savings, the use of rainwater, groundwater protection, low-carbon city and low-impact development (LID) and other concepts to enhance the generalization [4]In the following year, December 12, Xi Jinping, the General Secretary, clearly pointed out in the "central work conference urbanization": "the lifting of urban drainage system to give priority to the limited rain left, giving priority to greater use of natural forces drainage, construction of nature accumulating, natural infiltration, natural purification of sponge 
cities. "in March and April of this year, he stressed the idea of the construction of the sponge of the city. In February 11, 2014, the Ministry of Housing and Urban Construction Division in response to the People's Republic of China and eighteenth and eighteen third Plenary Session of the spirit, released the announcement of the "Urban Housing and Urban Construction Department Working Party points in 2014 ". One wrote, "Strengthening urban storm waterlogging prevention". First, the implementation of the "Urban Drainage (rain) in flood Integrated Planning Program", in conjunction with the Development and Reform Commission on the basis of special programs throughout the preparation of the "National Urban drainage waterlogging facility construction plan," for the central funds to support the project. The second is to urge the country to speed up the rain and sewage diversion transformation, improve the urban drainage waterlogging level, vigorously promote the construction of low-impact development mode, accelerate the construction of sponge research oriented city policy measures. "Mentioned in strengthening and building ecological garden city" to carry out urban green space rainwater utilization, urban wetland park construction and demonstration research programs. To develop "green space rainwater utilization technical specification (draft)," revised "Urban Wetland Park Planning and Design Guidelines", select the sunken green building pilot cities and other demonstration projects to achieve urban green space Regulating rainwater and other feature of the "city cavernous". All these indicate that the sponges are determined to build the city. In October 22, 2014, Xi Jinping ,the ministry of housing and Urban-Rural development of the People's Republic of China, had a general secretary's speech in response to and implementation of the "State Council on strengthening urban infrastructure," and "the State Council on urban drainage facilities do a good job in flood work notice, "the notice, preparation of the" sponge city construction technology Guide - low impact development storm water system construction (trial) ", so that the country should accord to their own situation, referring to the seaside city construction technical guidelines, made a sponge power together with the construction of the city [5]. The guidelines for the construction of sponge cities played a role in showing the way. In December 31, 2014, People's Republic of China Ministry of Finance, the Ministry of Housing and Urban-Rural Development and the Ministry of Water Resources by Xi Jinping, general secretary, made an important speech about "Strengthening the development of the sponge urban "and the central economic work conference instructions published by the central financial support to carry on Notify sponge urban construction pilot work, we decided to carry out the central financial support for construction pilot of the sponge urban. Note are: First, the central government to give special grant funds to the sponge urban construction pilot; the second is the pilot city joint declaration by the provincial finance, housing and urban construction, water conservancy departments. The third is to take the competitive assessment mode selection pilot cities; fourth is to carry out pilot work performance evaluation; Fifth, local financial, housing and urban construction, water conservancy departments should attach great importance to this work, actively planning, organization of urban program to implement, study and formulate supporting policies [1,6]. In April 2, 2015, the first batch of pilot cities sponge Urban Construction was announced in the list, including 16 cities, namely Qian'an, Baicheng, Zhenjiang, Jiaxing, Chizhou, Xiamen, Pingxiang, Jinan, Hebi, Wuhan, Changde, Nanning, Chongqing, Suining, Gui'an District and New West Ham. In this regard, the central government subsidies for the construction of more than 10 billion sponge city. For the construction of the city's requirements sponge permeability, stagnation, build, clean, with exhaust; Regulating plan hope to achieve the goal of building a rain total annual runoff flood control rate not less than $70 \%$ in 2020 , the pilot area of not less than $75 \%$ the corresponding control design rainfall of $23.2 \mathrm{~mm}$, total control runoff is 9.51 million cubic meters, initially built cavernous city. In April 27, 2016, the second batch of pilot cities sponge as Beijing, Tianjin, Dalian, Shanghai, Ningbo, Fuzhou, Qingdao, Zhuhai, Shenzhen, Sanya City, Yuxi City, Qing Shenyang city, Xining city and Guyuan in 14 cities [6]. Plus 16 in 2015, there are now 30 cities sponge city is the central financial support of urban construction pilot cities sponge. These pilot notifications effectively promote the city's construction of the sponge progress.

The situation analysis to the sponges city .For foreign cities, sponge research and practice has a wealth of experience, such as the UK's "sustainable urban drainage systems" that achieve the control 
of the rainfall runoff and the purpose of the urban water cycle [7]; the majority of the mixing conduit downtown Berlin, Germany the system can handle both rainwater and sewage, its advantage lies in the province of underground space; Swiss participatory "rain project", each will lead to roof rainwater tanks, the equivalent of China's cellar, with its water pump when used to suck out the life of miscellaneous water. This makes the maximum use of rainwater. However, the advantages of each city is different, and therefore cannot directly take over the practice of foreign countries with, each city should take for their own methods, play a role in the sponge. Our storm water control technology started in the 1980s. The center of gravity from the original rainwater recycling changed to rain and flood-control and water pollution control. In the last few years , for the rise of the "sponge city", China needs to learn from the success of the design rather than copying abroad, and the characteristics of the advantages of the city together, made of sponge for urban construction method [8-9].

\section{The development trend and recommendations to the sponge cities of China}

China's urban storm water systems will move closer to the LID mode later. Many people have realized that the traditional model has not suited to the drainage of modern society, it is our country's storm water drainage system that will slowly change, but it will not be suddenly accomplished [1].

It needs to promulgate laws and regulations related to storm water management, and perfect. According to the characteristics of different regions, local conditions LID technology research and development. Many also work together sector experts as well as people create their own sponge city [10]. We should also learn from foreign countries in rainwater collection, design implementation, experience LID BMPs and success stories, and provide recommendations for the city's construction of a sponge [11].

\section{Acknowledgements}

The authors are especially grateful to the financial support from the National Natural Science Foundation of China (51408146) and Guangxi Natural Science Foundation (2016GXNSFAA380204).

\section{References}

[1] D.J. Wu, S.Z. Zhan, Y.H Li. China Soft Science. Vol. 1 (2016), p. $79-97$ (In Chinese).

[2] H. Tong, J.L. Wang, W. Che, etc. South Building. Vol. 4 (2015), p. 108-114 (In Chinese).

[3] Y. Zhang, B.X. Yu, S.Q. Che, etc. Chinese gardens. Vol. 3 (2014), p. $49-53$ (In

Chinese).

[4] Y. Li . China Science and Technology Information, Vol. 5 (2015), p. 26-27 (In Chinese).

[5] Y. Yang, G.S. Lin. South Building. Vol. 3 (2015), p. 59-64 (In Chinese).

[6] K.J. Yu, D.H. Li, H. Yuan, Water supply and drainage in western. Vol. 6 (2015), p.

26-36(In Chinese).

[7] S.Q. Che, C.K. Xie, Dan Chen, and B.X. Yu. Chinese gardens. Vol. 6 (2015), p. 11-15

(In Chinese).

[8] W. Che, K. Zhang, and Y. Zhao. Construction Science and Technology. Vol. 1 (2015), p. 22-25

(In Chinese).

[9] B.X. Qiu. Urban-Rural Development. Vol. 2 (2015), p. 8-15 (In Chinese).

[10] Y. Zou, Y.Q. Xu, C.H. Qiu. Economic Geography. Vol. 9 (2015), p. $65-71$ (In Chinese). 
[11] Y.C. Zhang, J.P. Wang. Resource Development. Vol. 10 (2015), p. 1220-1223 (In Chinese). 